\title{
ANTIHYPERGLYCEMIC ACTIVITIES ETHANOL EXTRACT OF Musa paradisiaca $L$ STEMS AND DETERMINATION OF ITS ACTIVE COMPONENTS USING GC-MS
}

\author{
Mayang Sari ${ }^{1,2}$, Tamrin ${ }^{1, *}$, Jamaran Kaban ${ }^{1}$ and Zul Alfian ${ }^{1}$ \\ ${ }^{1}$ Department of Chemistry, Faculty of Mathematics and Natural Sciences, Universitas Sumatera \\ Utara, Medan-20155, Indonesia \\ ${ }^{2}$ Faculty of Pharmacy and Health, Institut Kesehatan Helvetia, Medan-20124, Indonesia \\ *E-mail: tamrin@usu.ac.id
}

\begin{abstract}
Various research on antihyperglycemic is continuously performed due to the fact every year the charge of diabetes patients increases. This study aims to find natural potentials that can be developed as an antihyperglycemic because existing synthetic drugs give unfavorable effects if used continuously. In this study, the natural potency of Musa Paradisiaca $L$ was developed as an anti-hyperglycemic agent with the hope that its use would not cause a prolonged effect. The extract of ethanol's Musa Paradisiaca L stem (EEMP) obtained by maceration was pretested by phytochemical screening. And obtained the presence of secondary metabolites, namely: Terpenoids, steroids, and saponins. Testing with GC-MS was also carried out to determine the active compound in ethanol extract which has potential as anti-hyperglycemia. The chromatogram results showed that the active compounds detected were: lupeol, stigmasterol, Cyclolanostan, and obtusifoliol. Previous studies of these components were able to lower blood sugar levels. The antihyperglycemic test was carried out in vivo on alloxan-induced mice. The treatment of diabetic mice was divided into 5 groups, namely: positive control, standard treatment, and treatment of extracts (100, 200, and 300 $\mathrm{mg} / \mathrm{kg} \mathrm{BW}$ ) was given orally. The progression of decreasing effect of extract and glibenclamide at the 8th day limit after alloxan induction. The study showed that there were not have significant differences between treatment EECL and glibenclamide. The hyperglycemic test results clearly show that the ethanol extract of Musa paradisiaca $\mathrm{L}$ stem has the potential in antihyperglycemic treatment.
\end{abstract}

Keywords: Musa.Paradisiaca L, GC-MS, Anti-hyperglycemic, Terpenoids, Saponin, Stigmasterol, Steroids

(C) RASĀYAN. All rights reserved

\section{INTRODUCTION}

Diabetes mellitus (DM) is a heterogeneous disorder caused by an increase in blood glucose levels caused by the hormone insulin. This causes various disorders the metabolism of fat, protein and in the long run, will cause irreversible changes in flow rate resulting in damage to insulin-producing organs. Because every year there is an increase in the number of DM sufferers, treatment for this disease is a top priority, either through drugs (pharmacological therapy) or without drugs (non-pharmacological therapy). ${ }^{1}$ So it is very important to always look for alternative drugs to prevent the increasing condition.

One of the plants provided in this case is the Musa paradisiaca L plant which we know as the Kepoks' banana (North Sumatra, Indonesia) which is a family of the Musa paradisiaca L. species. In various countries, about 300 banana varieties have been planted, mostly grown in tropical areas Asia and Australia. ${ }^{2}$ The ability to grow banana plants in Indonesia's tropical climate is very beneficial for this plant to be harvested at any time. So that Indonesia is one of the leading banana producers with various varieties. Several types of banana plants are rich in benefits ranging from roots, stems, leaves, and fruit. Various benefits the parts of the Musa paradisiaca $L$ plant have been used orally and topically as a medicine to treat diarrhea, colitis, and anti-inflammatory bowel disease. ${ }^{3,4}$ And traditionally used for dressing wounds, eye diseases, anemia, cachexia, bleeding, dysmenorrhea, menorrhagia, inflammation, and diabetes. The pseudostem juice of the Musa Paradisiaca L plant demonstrated protective toxic effects 
RASĀYAN J. Chem.

Vol. 13 | No. 4 |2508-2514| October - December | 2020

against snake venom. ${ }^{5}$ Unripe banana fruit extracted with methanol showed activity which indicated that the hydroxy peroxide level was decreased in mice. ${ }^{6}$ In the flower section of this plant has also been shown to be antimicrobial and antihyperglycemic. ${ }^{7}$ The stem water extract from this plant composed of $C$. dactylon exhibits hypoglycemic and antidiabetic effects. ${ }^{8}$ Previous research has shown that the methanol extract of the root part of the Musa Paradisiaca L plant composed of the Coccinia Indica plant can significantly control blood glucose levels in streptozotocin-induced test animals. ${ }^{9}$

Phytochemical screening in several studies, banana plant parts showed positive results in the presence of flavonoids. , terpenoids, tannins, and steroids/saponins. Based on previous research, it showed that the Musa paradisiaca L plant part had anti-hyperglycemic activity, so this study aimed to see the antihyperglycemic activity of Musa paradisiaca $L$ stem ethanol extract (EEMP) and determine its components by GC-MS.

\section{Collection of Musa Paradisiaca $L$ Stems}

\section{EXPERIMENTAL}

Steams of Musa paradisiaca Linn were collected from Muliorejo Deli Serdang village in April 2019. The plant was identified at Herbarium Medanense Universitas Sumatera Utara.

\section{Preparation and Extraction of Musa paradisiaca $L$ Stems}

Fresh stems of the plant are thinly sliced and dried in a drying cabinet for 5 days. Finish in an electric grinder. The fine powder (500 g) was extracted by maceration method (ethanol $96 \%$ ) for 3 days stored at room temperature and dark conditions. ${ }^{10}$ The residue from the first filter was then macerated again for the next 5 days. The first and second filtrate was collected for the next stage of the evaporating process using a rotary evaporator. ${ }^{11}$ The extract ethanol's Musa Paradisiaca L stems (EEMP) obtained as crude extract was $20.5 \mathrm{~g}(=4.1 \%)$

\section{Phytochemical Analysis}

Phytochemical screening has been carried out to determine the types of secondary metabolites in EEMP, including alkaloids, steroids/saponins, glycosides, tannins, phenolic compounds, and flavonoids according to standard methods. ${ }^{12,13}$

\section{Gas Chromatography and Mass Analysis}

The analysis was carried out using Shimadzu GCMS-QP2010S with Electron Energy: 10 to $200 \mathrm{eV}$ with helium at $1.51 \mathrm{ml}$ for 1 minute as a carrier gas. Detector: $0.85 \mathrm{kV}+0.00 \mathrm{kV}$. The injector temperature is $200{ }^{\circ} \mathrm{C}$, and the oven temperature is maintained at $70{ }^{\circ} \mathrm{C}$ for 3 minutes, rising to $200{ }^{\circ} \mathrm{C}$. The mass spectrometer is operated in electron effect mode at $70 \mathrm{eV}$ in the scanning range $50-500 \mathrm{~m} / \mathrm{z}$. Column Flow: $1.03 \mathrm{~mL} / \mathrm{min}$ Separation ratio is adjusted to 1:10.

\section{Experimental Animals}

This research was conducted using 25 mice (Rattus norvegicus Wistar strain) aged 8-12 weeks at a weight of 20-30 g. Animals are conditioned for a minimum of seven days in a field animal laboratory facility with 12 hours of bright / 12 hours dark lighting, room temperature $25^{\circ}-27^{\circ}$, and humidity $60-70 \%$.

The food for mice provided as water and standard animal pellets. ${ }^{10}$ Ethical approval is issued by the Animal Research Ethics Committee / AREC, Universitas Sumatera Utara with the registration number 0626 / KEPH-FMIPA / 2019

\section{Evaluation of Anthiperglicemic Extract Ethanol's Musa Paradisiaca L Stems (EEMP)}

In experimental animals that had been fasted for 12 hours, alloxan monohydrate $(10 \mathrm{mg} / \mathrm{L})$ was induced by intraperitoneal injection. ${ }^{13}$ Blood glucose levels were observed again after 48 hours of injection. This is done to observe a permanent and effective increase in glucose levels. Mice with hyperglycemia (blood glucose $>180 \mathrm{mg} / \mathrm{dL}$ ) were used to evaluate the blood sugar level group with the effect of oral administration of EEMP (with a concentration of 100,200,300 $\mathrm{mg} / \mathrm{kg}$ ), positive control (standard hypoglycemic drug glibenclamide $0.5 \mathrm{mg} / \mathrm{Kg}$ ) and negative control (CMC-Na $0,5 \%)$. The 5 groups $(\mathrm{n}=$ 5) were placed in different rooms. ${ }^{8,14}$ 
RASĀYAN J. Chem.

Vol. 13 | No. 4 |2508-2514| October - December | 2020

Observation of blood glucose levels $(\mathrm{mg} / \mathrm{dL})$ by taking mice blood in the tail was measured using an EasyTouch ${ }^{\circledR}$ glucometer, based on the glucose oxide method. Time to observe the glucose levels of the mice every 2 days until the blood sugar levels of the mice returned to normal. And oral fluids are given every day.

\section{Phytochemical Screening}

\section{RESULTS AND DISCUSSION}

Phytochemical screening as a preliminary test with standard procedures has been carried out on EEMP and the secondary metabolic identifications mostly are obtained terpenoids, steroid saponins, and steroids.

\section{GC-MS Analysis}

The results of the GC spectrum from the EEMP have been able to confirm the existence of 17 components with different retention times which can be seen in Fig.-1 and Table-1 as follows:

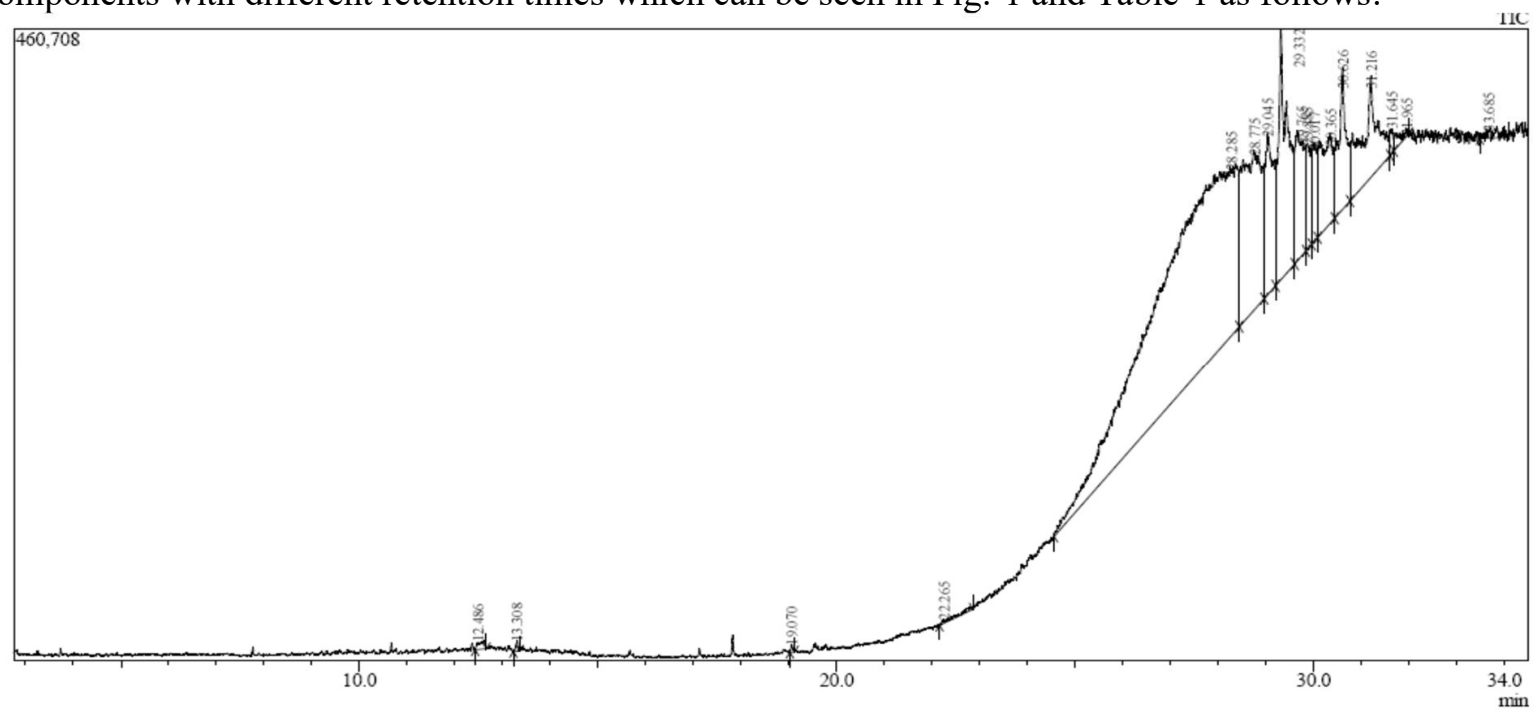

Fig.-1: Typical GC Spectrum Extract Ethanol's M. Paradisiaca L stems

Identification of peak EEMP was carried out by comparison with standard retention times, and mass spectra obtained compared to those available in the NIST library (NIST 14 - Mass Spectral Library, 2014 version).

Of the 17 components found in Extract Ethanol's M. Paradisiaca L stems, four bioactive components can be said to have benefits as secondary metabolites with a peak area of more than $4 \%$, namely: Lupeol, Stigmasterol, Cyclolanost, and Obtusifoliol

Table-1: Identification of Active Components in Extract Ethanol's M. Paradisiaca L stems

\begin{tabular}{c|l|c|c}
\hline & \multicolumn{1}{|c|}{ Name of Structure } & $\begin{array}{l}\text { Retention Time } \\
(\mathrm{min})\end{array}$ & $\mathrm{MW}(\mathrm{g}$ mol-1) \\
\hline 0,04 & Phytol & 19,07 & 296 \\
\hline 0,08 & Trichloroacetic acid, tridecyl ester & 13,31 & 344 \\
\hline 0,17 & $1,3,5-T r i a z i n e-2,4,6-t r i a m i n e$ & 12,49 & 126 \\
\hline 0,19 & Corticosterone & 22,27 & 346 \\
\hline 0,22 & Pentasiloxane, 1,1,3,3,5,5,7,7,9,9-decamethyl & 31,65 & 356 \\
\hline 0,33 & Trimethylsilyl 2-(5H-chromeno[2,3-b]pyridine & 31,96 & 327 \\
\hline 0,34 & Ethanethioic acid, S-[8-(diethylphosphono)octyl & 3,69 & 324 \\
\hline 1,67 & $\begin{array}{l}\text { Propionic acid, 3-(benzo[1,3]dioxol-5-yl)-3-(4- } \\
\text { methylbenzoylamino }\end{array}$ & 29,89 & 327 \\
\hline
\end{tabular}


RASĀYAN J. Chem.

Vol. 13 | No. 4 |2508-2514| October - December | 2020

\begin{tabular}{c|l|c|c}
\hline 1,59 & Sebacic acid, 4-bromo-2,6-difluorobenzyl isobutyl ester & 30,02 & 610 \\
\hline 3,69 & $9,19-C y c l o l a n o s t-24-e n-3-o l,(3 . b e t a)-$. & 30,63 & 426 \\
\hline 3,93 & Butyl 4-[(trimethylsilyl)amino]benzoate & 29,77 & 265 \\
\hline 4,14 & Lupeol & 30,37 & 426 \\
\hline 4,63 & Stigmasterol & 29,05 & 412 \\
\hline 5,49 & $9,19-C y c l o l a n o s t a n-3-o l, 24-m e t h y l e n e-$, & 31,22 & 440 \\
\hline 8,47 & Obtusifoliol & 29,33 & 426 \\
\hline 10,95 & Corticosterone 21-acetate & 28,78 & 388 \\
\hline 54,05 & $\begin{array}{l}\text { Heptasiloxane, } \\
\text { tetradecamethyl }\end{array}$ & 28,29 & 504 \\
\hline
\end{tabular}

\section{Active Component of EEMP}

Some of the bioactivity effects of active compounds obtained from identification with GC-MS can be understood by their activity as antihyperglycemic.

Lupeol compounds as natural pentacyclic triterpenes, phytochemically, are found in the skin, stems, and roots of plants which contain alkaloids and terpenoids. ${ }^{15}$ In some vegetables and fruits such as guava, cucumber, tomato, and white cabbage, this lupeol compound can also be found. ${ }^{16}$ And pharmacologically anti-inflammatory and capable of being involved in proliferation for tissue repair. ${ }^{17}$ Apart from that, it is also active against several acute diseases such as diabetes, kidney problems, cardiovascular disease, hepatotoxicity, cancer, and microbial infections ${ }^{18-20}$ From the chloroform extract of Parkia speciosa, the presence of stigmasterol and $\beta$-sitosterol was able to significantly reduce blood glucose levels in diabetic rats. ${ }^{14}$ And some vegetable sources containing sitosterol have been able to show antihyperglycemic activity and it is proven that $\beta$-cells of the pancreas can maintain insulin availability in controlling blood glucose (72-126 mg / dL). ${ }^{21}$

Obtusifoliol is a steroid compound isolated from Euphorbia Sogdiana proven to actively inhibit growth and cause apoptotic effects on breast cancer cells. ${ }^{22}$

The 19-cyclolanost-24-en-3-ol compound, which is from the Trigona spp Propolis fraction contains the most compounds (49.91\%) and has been tested with the highest antibacterial activity against E. coli. ${ }^{23}$ In the EEMP chromatogram of this study, it was obtained $9.18 \%$ with retention times of 30.63 and 31.22 minutes.

\section{Treatment Observations in Diabetic Mice}

Observation of changes in blood glucose levels of mice in each group can be observed in Table-2. and Fig.-2.

Table-2: Blood Glucose Level on EEMP Deficiency Animal Model

\begin{tabular}{l|l|l|l|l|l|l}
\hline & \multicolumn{7}{c}{ Mean blood glucose consentration (mg/dL) } & \\
\cline { 2 - 8 } \multicolumn{1}{c}{ Treatment } & $\begin{array}{l}\text { 1 day After } \\
\text { Alloxan }\end{array}$ & $\begin{array}{l}2 \text { day } \\
\text { Before } \\
\text { Alloxan }\end{array}$ & 3 day & 5 day & 7 day & 9 day \\
\hline $\begin{array}{l}\text { Glibenclamide (control } \\
\text { positive) }\end{array}$ & $86 \pm 4,88$ & $190,7 \pm 5,68$ & $162 \pm 4,66$ & $130 \pm 4,22$ & $97,7 \pm 6,66$ & $84 \pm 3,11$ \\
\hline Control negative & $82,2 \pm 3,83$ & $196,0 \pm 6,59$ & $186,2 \pm 9,01$ & $175,0 \pm 6,36$ & $160,6 \pm 4,88$ & $146,0 \pm 5,61$ \\
\hline EEMP 300 mg/kg bb & $89,2 \pm 5,03$ & $193,6 \pm 6,54$ & $152,6 \pm 6,95$ & $131 \pm 10,43$ & $107 \pm 3,19$ & $83,8 \pm 3,42$ \\
\hline EEMP 200 mg/kg bb & $87,4 \pm 3,85$ & $188,4 \pm 5,32$ & $161 \pm 7,0$ & $140,8 \pm 6,42$ & $112,4 \pm 7,76$ & $87,6 \pm 2,51$ \\
\hline EEMP 100 $\mathrm{mg} / \mathrm{kg}$ bb & $86,2 \pm 5,40$ & $187,6 \pm 3,29$ & $169,8 \pm 6,22$ & $145,2 \pm 6,98$ & $112,8 \pm 3,96$ & $95,8 \pm 1,48$ \\
\hline
\end{tabular}

Note: Data obtained from the average value of each test animal as much as 5 from each group $\pm \mathrm{SD}$,

Antihyperglycemic Effect of EEMP in Mice

Observations from Table-2, the first day show that all test animals are conditioned at normal blood glucose levels $(82-87 \mathrm{mg} / \mathrm{dL})$. The induction effect of alloxan $(10 \mathrm{mg} / \mathrm{L})$ used on mice on the second 
RASĀYAN J. Chem.

Vol. 13 | No. 4 |2508-2514| October - December | 2020

day was observed to have a significant increase in value (188-190.7 mg / L). Animals used to test for hyperglycemia had a number greater than $180 \mathrm{mg} / \mathrm{dL} .{ }^{24}$

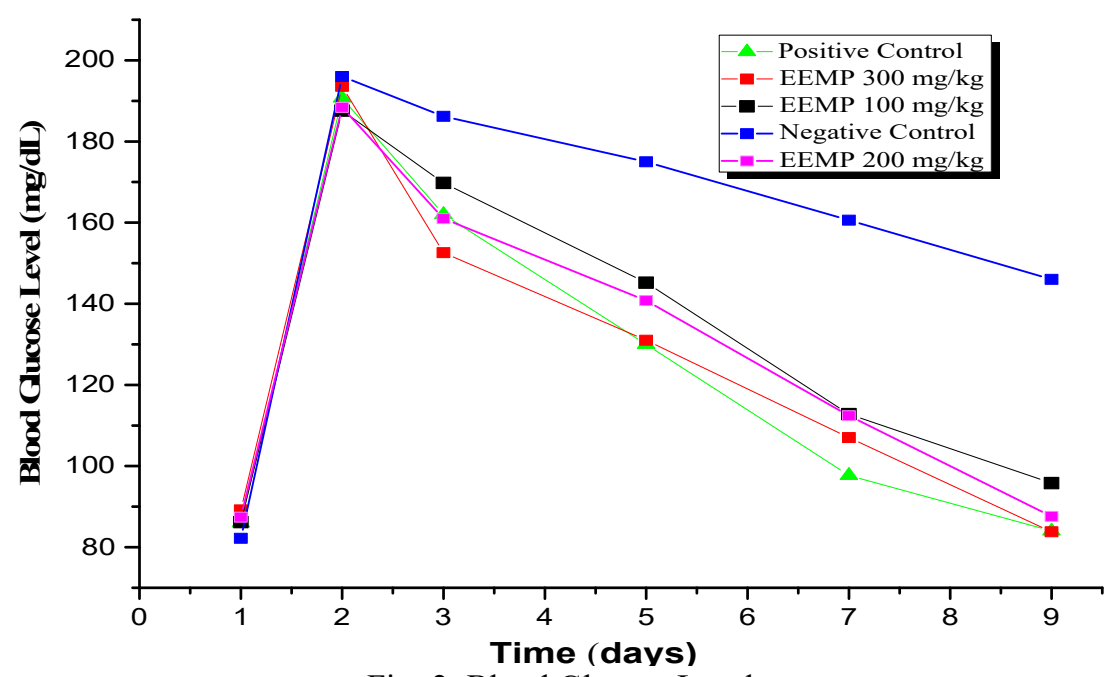

Fig.-2: Blood Glucose Level

The effect of alloxan compounds on mice tests animals can produce hydroxyl which is very reactive and can cause an increase in glucose levels on the second day. 12 hours alloxan after inducted, oral therapy in each group (positive and negative control, EEMP 100;200;300 mg / Kg), and each of 5 test animals was treated every day. After 24 hours of oral therapy, blood glucose levels were measured, it was seen that there was a decrease in each group of mice (Fig.-1). The last observation on 9 days showed four groups of test animals with normal conditions as on the first day. At a concentration of EEMP $300 \mathrm{mg} / \mathrm{Kg}$, it can match the use of Glibenclamide $(0.5 \mathrm{mg} / \mathrm{Kg})$ as a synthetic drug so that it can be said that EEMP is a natural ingredient that can be developed as an antihyperglycemic. However, in the negative control group, blood glucose levels were still high.

This decrease can occur due to an increase in insulin secretion, namely the number of pancreatic beta cells and Langerhans by the regenerated pancreatic organs even though there are hydroxyl radicals due to the influence of alloxan.

This is suspected by the presence of EEMP bioactive components that have secondary metabolites such as saponins, steroids, sterols, and terpenoids which can prevent the oxidation of pancreatic beta cells due to alloxan induction so that the damage can be minimized. The compounds contained in EEMP are Lupeol, Stigmasterol, Cyclolanostan, and Obtusifoliol. It is by following per under with the previous literature that secondary metabolites are antihyperglycemic and function as good antioxidants in the treatment of diabetes mellitus because of their ability to ward off reactive radicals in the pancreas. ${ }^{25}$

Lupeol, $\beta$-sitosterol, and Stigmasterol together in the chloroform fraction of P. cineraria bark have also been shown to have antidiabetic activity. Some of the pharmacological effects of stigmasterol are antiinflammatory, hypoglycemic, antioxidant, cytotoxic, anti-tumor, and anti-hypercholesterolemia effects. ${ }^{26}$ Research has also been carried out on stigmasterol isolated from the skin of Butea monosperm, which can significantly inhibit the thyroid and is hypoglycemic. ${ }^{27}$

Previous research on lupeol compounds, as compounds capable of lowering blood glucose levels in mice by activating insulin signal phosphatidylinositol 3-kinate and protein tyrosine phosphatase, which greatly contribute to the antidiabetic effect. ${ }^{28}$

\section{CONCLUSION}

From the information above, it is clear that extract ethanol's Musa paradisiaca $L$ stems contain several active components as an antihyperglycemic agent. Alloxan injection has been shown to increase blood glucose levels, and in the positive control treatment or extract, it decreased significantly. These active components include lupeol, stigmasterol, cyclolanost, and obtusifoliol can beneficiate the damaged pancreas in warding off radicals due to cell oxidation caused by alloxan induction. So it is very important 
RASĀYAN $J$. Chem.

Vol. 13 | No. 4 |2508-2514| October - December | 2020

to do further research to evaluate the potential of natural constituents of Musa Paradisiaca L plant that have not been utilized. Therefore it is important to further investigate this compound.

\section{ACKNOWLEDGMENT}

Mayang Sari was grateful to the LPDP Indonesia for financial assistance to complete my research.

\section{REFERENCES}

1. A. Artarini , I. K. Adnyana, Rasayan Journal of Chemistry, 12(1), 157(2019), DOI: 10.31788/RJC.2019.121505

2. K. Lavanya, World Journal Pharmaceutical and Medical Research, 2(6), 163(2016), ISSN: 24553301

3. A. Hussain , M. N. Khan, Z. Iqbal, M.S. Sajid, M. K. Khan, Journal of Veterinary Parasitology, 179(1-3), 92(2011), DOI:10.1016/j.vetpar.2011.02.022

4. M. Correa, M.C. Mesomo, K.E. Pianoski , Y.R. Torres , M.L. Corazza, The Journal of Supercritical Fluids, 113, 128(2016), DOI:10.1016/j.supflu.2016.03.01

5. M.H. Borges , D.L.F. Alves, D.S. Raslan, D. Piló-Veloso, V.M. Rodrigues, Homsi-Brandeburgo MI, Journal of Ethnopharmacology, 98(1-2), 21 (2005), DOI: 10.1016/j.jep.2004.12.014

6. S. Vijayakumar, G. Presannakumar, N.R. Vijayalakshmi, Fitoterapia Journal, 79(4), 279(2008), DOI: 10.1016/j.fitote.2008.01.007

7. S. Jawla, Y. Kumar, M.S.Y. Khan, Asian Pacific Journal of Tropical Biomedicine, (2 SUPPL.), S914(2012), DOI: 10.1016/S2221-1691(12)60336-0

8. P.K. Rai, D. Jaiswal, N.K. Rai , S. Pandhija, A.K. Rai , G. Watal, Journal of Lasers in Medical Science, 24(5), 761(2009), DOI:10.1007/s10103-008-0637-0

9. C.Mallick, D.De, D.Ghosh, Journal of Pancreas, 38(3), 322(2009), DOI: 10.1097/MPA.0b013e318192ebdf

10. S.M. Sinaga, G. Haro, S. Sudarmi, Iksen, Rasayan Journal of Chemistry, 12(4), 1992(2019), DOI: 10.31788/RJC.2019.1245451

11. K. Swarnalatha, C.V. Kishore Babu, B.H. Babu, Rasayan Journal of Chemistry, 12(2), 907(2019), DOI: $10.31788 /$ RJC.2019.1225168

12. J.B. Harborne, Progress in the Chemistry of Organic Natural Products, 14, 1470(1975), DOI: 10.1016/S0031-9422(00)98679-7

13. F. Jamaluddin, S.Mohameda, M.N. Lajis, Food Chemistry Journal Elsevier, 54(1), 9(1995), DOI: 10.1016/0308-8146(95) $92656-5$

14. S. Kumar, S.Sharma, N. Vasudeva, V. Ranga, Biomedicine and Pharmacotherapy Journal , 108(May), 1051(2018), DOI:10.1016/j.biopha.2018.09.099

15. F.N. Melo, V.R. Navarro, M. S. Da Silva, E.V.L. Da-cunha, J.M. Barbosa-Filho, R. Braz-filho, Journal of Natural Product Letters, 15(4), 261(2001), DOI: 10.1080/10575630108041290

16. M. Saleem, Journal of Cancer Letters, 285(2), 109(2009), DOI:10.1016/j.canlet.2009.04.033

17. F.P. Beserra, M. Xue , G.L. De Azevedo Maia , A.L. Rozza, C.H. Pellizzon, C.J. Jackson, Journal of Molecules, 23(11), 2819(2018), DOI:10.3390/molecules23112819

18. H. Badshah, T. Ali , S. Ur Rehman, F.Ul Amin, F. Ullah, T.H Kim, Journal of Neuroimmune Pharmacology, 11(1), 48(2016), DOI:10.1007/s11481-015-9623-z

19. Yokoe, K. Azuma, K. Hata, T. Mukaiyama, T. Goto, T. Suka, Journal of Molecular And Clinical Oncology 3, 89(2015), DOI:10.3892/mco.2014.450

20. V. Sudhahar, S. Ashok Kumar, P. Varalakshmi, V. Sujatha, Journal of Molecular and Cellular Biochemistry, 317, 11(2008), DOI:10.1007/s11010-008-9786-5

21. R. Balamurugan, A. Stalin, S. Ignacimuthu, European Journal of Medicinal Chemistry, 47(1), 38(2012), DOI:10.1016/j.ejmech.2011.10.007

22. M. Aghaei, Z. Yazdiniapour, M. Ghanadian, B. Zolfaghari, V. Lanzotti, V. Mirsafaee, Journal of Steroids, 115, 90(2016), DOI:10.1016/j.steroids.2016.07.008

23. A. Endang, Z. Hasan, I.M. Artika, G.D. Tukan, Global Journal of Biology, Agriculture \& Health Sciences , 3(1), 215(2014). 
RASĀYAN J. Chem.

Vol. 13 | No. 4 |2508-2514| October - December | 2020

24. C. Ashley, N. Fong, Wah Cheung, Journal of Diabetes Research and Clinical Practice, 99, 277 (2013), DOI: 10.1016/j.diabres.2012.12.023

25. A. El Barky, S.A. Hussein, Diabetes Journals / Diabetes Management, 7(1), 148(2017)

26. L.K. Soni, M.P. Dobhal, D. Arya, K.Bhagour, P. Parasher, R.S. Gupta, Biomedicine and Pharmacotherapy Journal, 108(5), 1015(2018), DOI:10.1016/j.biopha.2018.09.099

27. S. Panda, M. Jafri, A. Kar, B.K Meheta, Fitoterapia Journal, 80(2), 123(2009), DOI: 10.1016/j.fitote.2008.12.002

28. D. Tang, Q. Chen, X. Xin, H. Aisa, Biomedicine and Pharmacotherapy Journal, 87, 145(2017), DOI:10.1016/j.biopha.2016.12.058

[RJC-5802/2020] 